\title{
KAJIAN KEBIJAKAN MODAL SOSIAL DALAM MENYELESAIKAN KONFLIK TAMBANG PADA MASYARAKAT PESISIR
}

\author{
Fitriansyah \\ Bappeda Provinsi Kepulauan Bangka Belitung \\ e-mail:21fitriansyah@gmail.com
}

\begin{abstract}
Abstrak: Konflik sosial selalu terjadi karena perbedaan kepentingan dalam kehidupan masyarakat. Begitu juga yang terjadi pada masyarakat pesisir sebagai akibat dari ekses negatif dalam melakukan aktivitas pertambangan, sehingga apabila kondisi ini tidak dikelola dengan bijaksana dapat menyebabkan pertentangan yang merugikan pihak-pihak yang berkepentingan. Penulisan ini bertujuan untuk menganalisis dan mengkaji penerapan modal sosial sebagai sebuah kebijakan dalam menyelesaikan konflik. Metode penulisan adalah deskriptif kualitatif, yaitu mengkaji beberapa literatur yang berkaitan dengan penanganan konflik sosial, salah satunya adalah mengembangkan modal sosial yang ada pada masyarakat. Representasi modal sosial masyarakat dikembangkan oleh pemerintah melalui Kementerian Sosial RI sebagai sebuah kebijakan dalam menyelesaikan konflik sosial, dengan asumsi bahwa modal sosial dapat melahirkan permufakatan bersama di dalam masyarakat untuk menjawab persoalan-persoalan yang mengarah pada terjadinya konflik sosial. Kesimpulan penulisan ini menunjukkan bahwa, pengembangan modal sosial melalui program keserasian sosial secara fungsional belum secara maksimal dimanfaatkan, karena berbagai kendala yang dihadapi. Sehingga diperlukan solusi dan strategi yang tepat dalam mengembangkan kebijakan tersebut.
\end{abstract}

Kata Kunci: Modal Sosial; Konflik Tambang; Masyarakat Pesisir

Abstract: Social conflicts always occur because of interests in people's lives. Likewise, what happens to coastal communities as a result of negative excesses in carrying out mining activities, so that this environmental condition is not managed wisely and can cause conflicts that are detrimental to the parties concerned. This writing aims to analyze and examine the application of social capital as a policy in resolving conflicts. Qualitative descriptive method, which examines some literature related to the handling of social conflicts, one of which is developing the existing social capital in society. Reference to social capital developed by the government through the Ministry of Social Affairs of the Republic of Indonesia as a policy in resolving social conflicts, with the assumption that social capital can generate collective consensus in society to answer problems that lead to social conflict. The conclusion of this conclusion shows that the development of social capital through social harmony programs are functionally not fully utilized, because of the various connecting services. So that we need the right solutions and strategies in developing these policies.

Keyword: Social Capital; Mining Conflict; Coastal Communities 


\section{PENDAHULUAN}

Tulisan ini bertujuan untuk mencari solusi terhadap penyelesaian konflik sosial yang terjadi pada masyarakat pesisir di Provinsi Kepulauan Bangka Belitung. Masalah ini sangat penting dikaji karena menyangkut dua kepentingan yang berbeda dalam memanfaatkan sumber daya alam, yaitu antara masyarakat pesisir dengan yang melakukan aktivitas pertambangan laut, baik yang dilakukan secara perorangan, kelompok maupun kelembagaan. Hasil kaijan ini bermanfaat untuk menjaga kelangsungan hidup masyarakat pesisir di satu sisi, dan disisi lain kegiatan aktivitas pertambangan yang merupakan bagian dari proses pembangunan dalam sektor ekonomi dapat tetap dilaksanakan, namun dengan memperhatikan aspek keberlanjutan.

Sepanjang pengetahuan penulis, studi masalah ini masih sangat terbatas. Beberapa studi sebelumnya pernah dilakukan oleh Mustamin (2016), Cadith, Juliannes (2019) serta Bidayani, Endang dan Kurniawan (2020). Hasil studi tersebut menunjukkan bahwa konflik disebabkan oleh beberapa kepentingan yang berbeda. Sementara itu cara untuk menyelesaikan konflik adalah melalui proses negosiasi. Sedangkan tujuan penyelesain konflik adalah untuk menghindari masalah hukum. Hal ini sejalan dengan yang diungkapkan oleh Mustamin (2016 : hal.185), yang menyatakan Konflik Sosial adalah pertentangan antar kelompok dalam masyarakat yang sifatnya menyeluruh, yang disebabkan oleh adanya beberapa perbedaan. Perbedaan tersebut diantaranya adalah berbeda secara individu, pola budaya, status sosial, dan kepentingan.

Resolusi konflik merupakan kolaborasi yang memadukan antara unsur masyarakat pengguna, dalam hal ini kelompok nelayan dan penambang inkonvensional serta pemerintah yang dikenal dengan Co-management yang menghindari peran dominan yang berlebihan dari satu pihak dalam pengelolaan sumberdaya pesisir dan laut melalui pendekatan negosiasi (Endang Bidayani dan Kurniawan: 2020, hal 22). Sementara itu menurut Juliannes Cadith (2019 : hal. 16), Tujuan Penyelesaian konflik adalah untuk memfasilitasi proses pembuatan keputusan oleh kelompok-kelompok yang bersengketa, sehingga sedapat mungkin menghindari penyelesaian masalah melalui meja hukum.

Sebagaimana diketahui bahwa Masyarakat Pesisir adalah sekelompok masyarakat yang hidup dan menetap di kawasan pesisir dan laut serta melaksanakan fungsi sosial ekonominya dengan menggantungkan kebutuhan hidup dengan memanfaatkan sumber daya pesisir. Menurut Kartika dewi (2018 : hal. 34), Masyarakat pesisir adalah masyarakat yang mendiami wilayah sekitaran pesisir dan biasanya menggantungkan hidupnya pada laut sebagai sumber mata pencaharian. Masyarakat pesisir memiliki karakteristik dan budaya yang khas dengan menyesuaikan terhadap lingkungan dan alam sekitar. Masyarakat pesisir khususnya nelayan mempunyai ketergantungan yang tinggi terhadap ekosistem terumbu karang yang menjadi sumber penangkapan ikan sebagai mata pencahariannya (Latip Waratsangka, Yayat Dhahiyat, dan Sunardi : 2014, hal : 11). Karakteristik sebagai masyarakat pesisir lambat laun akan punah seiring dengan terancamnya kelestarian lingkungan laut dan pantai sebagai akibat penambangan lepas pantai yang dilakukan oleh pelaku tambang. 
Kajian ini dibatasi pada masalah penanganan konflik sosial antara masyarakat pesisir dan pelaku tambang melalui pengembangan modal sosial yang ada pada masyarakat untuk dikembangkan sebagai salah satu alternatif kebijakan dalam mengatasi masalah konflik. Hal itu karena masyarakat yang memiliki modal sosial yang tinggi cenderung bekerja secara gotong royong serta mampu dalam mengatasi permasalahan. Penulis menduga bahwa kekuatan modal sosial ini belum sepenuhnya dimanfaatkan oleh pengambil kebijakan (policy maker) ataupun pihak-pihak yang berkepentingan dalam suatu komunitas tertentu yang mengalami konflik sosial.

\section{KAJIAN PUSTAKA}

Konflik Sosial yang terjadi pada masyarakat pesisir diakibatkan karena dua kepentingan yang berbeda dalam mengelola sumber daya alam. Pihak-pihak yang berkepentingan adalah para nelayan dan pelaku tambang. Nelayan merasa terganggu dengan aktivitas pertambangan yang mengabaikan kaedah-kaedah pelestarian lingkungan sehingga merusak terumbu karang yang merupakan potensi sumber daya kelautan bagi para nelayan. Karakteristik masyarakat pesisir menurut Kartika Dewi (2018 : hal 34) dalam Jurnal yang berjudul "Pelapisan Sosial-Budaya Pesisir Kelurahan Mangkang Kulon Semarang", adalah masyarakat yang mendiami wilayah sekitaran pesisir dan biasanya menggantungkan hidupnya pada laut sebagai sumber mencari penghasilan. Sedangkan Konflik Sosial menurut Drs. Mustamin, M.Si dalam Jurnal yang berjudul "Studi Konflik Sosial dI Desa Bugis dan Parangina Kecamatan Sape Kabupaten Bima Tahun 2014" merupakan pertentangan antar kelompok dalam masyarakat yang sifatnya menyeluruh, yang disebabkan oleh adanya beberapa perbedaan. Perbedaan tersebut diantaranya adalah berbeda secara individu, pola budaya, status sosial, dan kepentingan. Fisher et al (2001) dalam Jurnal yang ditulis oleh Juliannes Cadith (2019 : hal. 5) yang berjudul "Konflik Dalam Pemanfaatan Sumber Daya di Pesisir Teluk Banten”, membagi pola konflik dalam tiga bentuk, yakni konflik laten, konflik terbuka dan konflik di permukaan. Dalam penanganan konflik sosial, pemerintah telah mengeluarkan kebijakan melalui Program Keserasian Sosial. Program Keserasian Sosial merupakan pengembangan dari modal sosial yang ada dalam kehidupan masyarakat. Berdasarkan kajian yang penulis lakukan terhadap jurnal yang berjudul "Konflik Sosial dan Program Keserasian Sosial" (Ardiwijadja, N. : 2017) serta "Implementasi Program Keserasian Sosial di Kota Palu Berbasis Masyarakat di Kota Palu" (Azmi : 2017), dapat disimpulkan bahwa Program Keserasian Sosial dapat dijadikan sebagai salah satu kebijakan penangan konflik sosial yang terjadi di masyarakat pesisir, namun dalam pelaksanaannya masih fokus ke pendekatan fisik dan bersifat sektoral, sehingga secara fungsional belum mencapai tujuan yang diharapkan.

\section{METODE PENULISAN}

Secara metodologis, penulisan makalah ini menggunakan pendekatan kualitatif dengan melakukan kajian literatur dalam membahas kerangka konseptual tentang konflik sosial yang 
terjadi pada masyarakat pesisir, Regulasi tentang pertambangan, kontribusi dan peranan pertambangan dalam pembangunan berkelanjutan serta penanganan konflik sosial dengan memanfaatkan modal sosial yang ada di masyarakat, melalui Program Keserasian sosial yang telah diterapkan pemerintah di beberapa daerah yang terjadi konflik. Penulis mencoba mendeskripsikan kaitan dari beberapa literatur yang berkaitan dengan masalah tersebut untuk mempertajam pendapat penulis dalam memberikan rekomendasi sesuai tujuan dari penulisan makalah ini. Adapun teknik pengumpulan data dilakukan dengan studi dokumentasi secara sekunder yaitu data diambil dari berbagai literatur, yang terdiri dari 11 (sebelas) Jurnal, 5 (lima) Website Pemerintah dan lembaga, Undang-Undang Republik Indonesia, termasuk dokumen hasil evaluasi program keserasian sosial dalam penanganan konflik sosial yang dikeluarkan oleh Pusat Penelitian dan Pengembangan Kementerian Sosial RI. Kemudian dianalisis dan dijadikan sebuah tulisan berupa makalah.

\section{HASIL DAN PEMBAHASAN}

\section{Tinjauan Terhadap Regulasi Tambang Laut Dan Pengelolaan Kawasan Pesisir}

Regulasi merupakan suatu bentuk rumusan aturan-aturan tertentu yang mengatur individu, kelompok atau masyarakat agar dapat mengendalikan perilaku dalam melaksanakan interaksi sosial sehingga dapat menciptakan ketertiban dalam masyarakat. Secara umum bentuk regulasi dapat berupa nilai-nilai, norma maupun produk hukum. Secara teknis regulasi dapat berupa kebijakan, program, dan kegiatan. Nilai-nilai dan norma adalah sesuatu yang menjadi kebiasaan dan disepakati bersama untuk dipedomani dan diyakini sebagai sesuatu hal yang baik. Sedangkan Produk hukum merupakan aturanaturan yang mengikat yang harus dipatuhi setiap orang atau lembaga dalam situasi tertentu yang ditetapkan oleh pemerintah maupun pemerintah daerah. Contoh produk hukum yang ditetapkan oleh pemerintah seperti Undang-Undang, Peraturan Pemerintah dan Peraturan Menteri. Sedangkan produk hukum yang ditetapkan pemerintah daerah dapat berupa Peraturan Daerah ataupun Peraturan Kepala Daerah. Dasar regulasi atau kebijakan publik di bidang pertambangan adalah UUD 1945 pasal 33 ayat 3 yang menyatakan bahwa : "bumi dan air dan kekayaan alam yang terkandung di dalamnya dikuasai oleh negara dan dipergunakan sebesar-besarnya untuk kemakmuran rakyat". Beberapa regulasi telah ditetapkan pemerintah untuk mengatur masalah pertambangan, seperti Undang-undang Nomor 4 Tahun 2009 Tentang Pertambangan Mineral dan Batubara, Peraturan Menteri ESDM Nomor 11 Tahun 2018 tentang Tata Cara Pemberian Wilayah, Perizinan dan Pelaporan pada Kegiatan Usaha Pertambangan Mineral dan Batubara, Peraturan Pemerintah Nomor 22 Tahun 2010 tentang Wilayah Pertambangan, serta Peraturan Daerah Nomor 7 Tahun 2014 tentang Pengelolaan Pertambangan Mineral. Keseluruhan regulasi tersebut merupakan sebuah keputusan atau tindakan yang diambil pemerintah dan pemerintah daerah untuk mengatur tatalaksana pertambangan agar terciptanya 
keseimbangan antara usaha-usaha pertambangan dan ekosistem sumber daya kelautan. Dalam UU No. 4 Tahun 2009 tentang pertambangan mineral dan batubara, dijelaskan bahwa pertambangan mineral dan batubara merupakan kegiatan usaha pertambangan yang mempunyai peranan penting dan vital dalam memberikan nilai tambah terhadap pertumbuhan ekonomi nasional dan pembangunan daerah secara berkelanjutan, namun harus juga dilakukan dengan memadukan kemampuan lingkungan, sumber daya alam, dan teknologi ke dalam proses pembangunan untuk menjamin generasi yang akan datang (www.researchgate.net).

Pemerintah Daerah Provinsi Kepulauan Bangka Belitung juga mempunyai tanggung jawab terhadap pengelolaan kawasan pesisir yang beririsan dengan kawasan pertambangan untuk menjaga kesinambungan potensi ekonomi sektor pertambangan, serta disisi lain Pemerintah Provinsi Kepulauan Bangka Belitung juga bertanggung jawab terhadap kelestarian lingkungan serta menjamin kesejahteraan masyarakat, khususnya masyarakat yang tinggal di daerah pesisir. Peraturan Daerah Nomor 3 Tahun 2020 tentang Rencana Zonasi Wilayah Pesisir dan Pulau-pulau Kecil (RZWP3K) merupakan bukti tanggung jawab pemerintah daerah untuk meningkatkan kesejahteraan masyarakatnya. Sebagaimana diuraikan dalam Penjelasan Umum Perda Nomor 3 Tahun 2020, bahwa Provinsi Kepulauan Bangka Belitung, mempunyai peran penting dalam menerapkan strategi pengembangan ekonomi lokal dan menciptakan peluang investasi. Peraturan Daerah RZWP3K Provinsi Kepulauan Bangka Belitung Tahun 2020-2040, memuat arah kebijakan lintas sektor dalam pembangunan pesisir dan pulau-pulau kecil, yang meliputi kegiatan perencanaan, pengelolaan, pengawasan, dan pengendalian terhadap interaksi manusia dalam memanfaatkan sumberdaya serta proses alamiah secara berkelanjutan dalam upaya meningkatkan kesejahteraan masyarakat (www.babelprov.go.id). Namun disisi lain, kehadiran Peraturan Daerah (PERDA) ini tidak semuanya diterima oleh banyak pihak. Ada pihak-pihak yang berkepentingan menolak kehadiran PERDA ini karena belum dapat mengakomodir kepentingan nelayan dan masyarakat pesisir. Sebagaimana diungkapkan oleh Direktur Wahana Lingkungan Hidup (WALHI) Bangka Belitung, Jessix Amundian, bahwa WALHI menilai Peraturan daerah (Perda) Rencana Zonasi Wilayah Pulau-Pulau Kecil (RZWP3K) yang baru disahkan, mengancam kerusakan lingkungan hidup dan memiskinkan nelayan di Pulau Bangka (mediaindonesia.com). Perbedaan pandangan (dissenting opinion) tersebut dikhawatirkan pada kondisi tertentu apabila tidak dapat dipertemukan, dapat menimbulkan konflik sosial di masyarakat, khususnya masyarakat pesisir, serta akan menghambat penyelenggaraan tugas-tugas pemerintah dan pembangunan di Bangka Belitung. 


\section{Kontribusi Sektor Pertambangan Bagi Perekonomian Daerah serta Bentuk Konflik Masyarakat Pesisir Dengan Pelaku Tambang}

a. Kontribusi Sektor Pertambangan

Tidak dipungkiri bahwa sektor pertambangan masih mendominasi terhadap perekonomian Bangka Belitung, walaupun sesungguhnya potensi sektor ini di masa yang akan datang akan habis dan tidak menjamin sebagai sektor unggulan yang berkelanjutan. Kontribusi Realisasi Penerimaan Negara Bukan Pajak (PNBP) atas sektor mineral dan batubara pada Desember 2018 tercatat mencapai Rp.46,6 triliun (detikfinance.com : 2019). Sedangkan kontribusi hasil tambang terhadap perekonomian Bangka Belitung mempunyai pengaruh yang besar terhadap pertumbuhan ekonomi Bangka Belitung. Dalam rentang waktu 5 (lima) tahun ke belakang pengaruh komoditas ini sangat signifikan terhadap pertumbuhan ekonomi Bangka Belitung. Hal ini sejalan dengan yang disampaikan Sulista (2019 : hal 64), bahwa turunnya harga timah menjadi salah satu penyebab terjadinya perlambatan ekonomi Provinsi Kepulauan Bangka Belitung dalam kurun waktu Tahun 2011 hingga Tahun 2015, yaitu dari 6,90 persen menjadi 4,08 persen. Selanjutnya berdasarkan hasil penelitian yang dilakukan oleh Sulista dan Rosyid (2018), dari kajian rata-rata analisis PDRB ADHK 2010-2017, untuk sektor pertambangan timah menempati urutan ke-3 dari 43 sub sektor, yaitu sebesar 10,72\%. Industri pengolahan timah menempati urutan ke-1, yaitu sebesar 14,61 $\%$ serta untuk 9 sektor perekonomian, menyokong sebesar 10,77 triliun rupiah PDRB Bangka Belitung (bappeda.babelprov.go.id). Begitu juga disaat pertumbuhan ekonomi Bangka Belitung tahun 2019 Anjlok ke peringkat dua paling bawah di antara provinsi se - sumatera, yaitu pada angka 3,32\%, karena disebabkan oleh anjloknya harga dari beberapa komoditas Bangka Belitung, yaitu salah satunya adalah Timah.

Disamping itu, kontribusi perusahaan pertambangan dalam hal ini PT. Timah yang beroperasi di Bangka Belitung telah banyak memberikan Berbagai kegiatan positif di sekitar wilayah operasi. Kontribusi perusahaan pertambangan yang dilakukan dapat berupa program wajib Corporate Social Responsibility (CSR) yang merupakan tanggung jawab perusahaan kepada masyarakat sekitar sebagai konsekuensi dari timbulnya dampak sosial, ekonomi dan lingkungan dari beroperasinya perusahaan tersebut. Program lain yang dilaksanakan adalah melalui Program Kemitraan Bina Lingkungan yang dirasakan ikut mendorong perekonomian masyarakat. Belum lagi program charity yang berupa bantuan sosial. Berdasarkan statistik bantuan CSR PT. Timah, total anggaran program CSR yang telah dikucurkan kepada masyarakat kurun waktu tahun 2009 s.d 2013 berkisar sebesar Rp. 117,3 M. Sedangkan untuk Program Bina Lingkungan sebesar Rp. 32,8 M, serta Program Pembinaan Usaha Kecil dan Koperasi sebesar Rp. 83,4 M (www.timah.com). 
b. Bentuk Konflik Masyarakat Pesisir dengan Perusahaan Pertambangan

Besarnya pengaruh komoditas pertambangan ini tidak hanya membawa keuntungan secara ekonomi semata, tetapi juga banyak menimbulkan ekses negatif terhadap kehidupan sosial masyarakat Bangka Belitung. Dampak negatif yang muncul dari aktivitas pertambangan ini adalah menurunnya kualitas lingkungan, khususnya ekosistem terumbu karang yang merupakan sumber potensial bagi mata pencaharian masyarakat pesisir, yang pada akhirnya dapat menyebabkan menurunnya pendapatan nelayan. Hal ini dapat terjadi apabila pelaku pertambangan dalam melaksanakan eksplorasi pertambangan mengabaikan kepentingan nelayan serta kaidah-kaidah kelestarian lingkungan. Apalagi dengan maraknya penambang-penambang ilegal yang beroperasi di daerah tertentu yang hanya mengejar keuntungan semata. Bila ekses negatif ini dibiarkan dan tidak dikelola dengan baik akan menimbulkan konflik sosial antara masyarakat pesisir dengan pelaku pertambangan, yang akan menyebabkan kerugian di antara kedua belah pihak. Sebagaimana dijelaskan oleh Jeanne Darc Noviyanti Manik (2014) :

"Tidak ada pertambangan yang tidak merusak lingkungan, baik di darat maupun di laut. Kerusakan akan membawa dampak bagi beberapa dekade mendatang bahkan bisa menjadi permanen. Penambangan timah lepas pantai tanpa dilandasi dasar hukum, dapat merusak terumbu karang, mencemari pantai, dan mengganggu perkembangan perikanan serta dapat mengganggu sistem sosial. Potensi besar dalam jangka panjang akan habis, hanya untuk mengisi nafsu keuntungan yang sesaat. Jika hal ini terus berlanjut, pada titik klimaks, bukan tidak mungkin bahwa akan ada perselisihan atau penjarahan yang dilakukan oleh nelayan yang merasa dirugikan dengan penambang" (Jeanne Darc Noviyanti Manik : 2014)".

Di dalam setiap kehidupan sosial termasuk juga pada masyarakat pesisir, tidak ada satupun manusia yang memiliki kesamaan yang persis, baik dari unsur perilaku, budaya, kepentingan, keinginan, tujuan dan sebagainya. Sehingga berbagai reaksi yang ditimbulkan sebagai bentuk dari konflik yang terjadi disebabkan karena ketidaksamaan kepentingan, khususnya dalam hal ini muncul reaksi-reaksi penolakan, bahkan sampai menyebabkan terancamnya keberlangsungan kepentingan yang lainnya. Konflik mengandung unsur sebuah permusuhan atau pertentangan. Konflik Juga sering kali berubah menjadi kekerasan, terutama dalam upaya mengelola konflik tidak dilaksanakan dengan sungguh-sungguh oleh pihak yang berkepentingan. Menurut Mustamin (2016 : hal. 185) menyebutkan konflik merupakan suatu proses sosial individu atau kelompok yang berusaha untuk memenuhi keinginannya dengan cara melakukan pertentangan dengan pihak lawan yang disertai dengan ancaman dan/atau kekerasan. Fisher et al.,(2001) dalam Juliannes Cadith (2019 : hal. 5), membagi pola 
konflik dalam tiga bentuk, yakni 1) konflik laten yang bersifat tersembunyi dan perlu diangkat ke permukaan untuk ditangani secara efektif, 2) konflik terbuka, yaitu konflik yang berakar dalam dan sangat nyata, dan memerlukan berbagai tindakan untuk mengatasi akar penyebab dan berbagai macam dampaknya, dan 3) konflik di permukaan memiliki akar yang dangkal atau tidak berakar dan muncul hanya karena kesalahpahaman mengenai sesuatu yang dapat diatasi dengan menggunakan komunikasi. Lebih lanjut Fisher et al.,(2001) dalam Endang Bidayani dan Kurniawan (2020 : hal. 15) menjelaskan bahwa, konflik disebabkan karena kebutuhan manusia baik fisik, mental maupun sosial ada yang tidak terpenuhi. Selaras dengan pendapat Fisher et al.,(2001), pemicu konflik dalam pemanfaatan sumberdaya pesisir di Kabupaten Bangka Tengah menurut Endang Bidayani dan Kurniawan (2020 : hal. 18) dikelompokkan menjadi 4 (empat) isu, yaitu 1) isu lingkungan berupa kerusakan terumbu karang, pendangkalan dan menurunnya kualitas air, 2) isu sosial meliputi pendidikan anak, kesehatan nelayan dan kesempatan kerja, 3) isu pelanggaran hukum, yaitu muncul tambang inkonvensional yang ilegal, serta 4) isu ekonomi, yaitu disebabkan oleh disparitas pendapatan antara nelayan dengan penambang timah.

Bentuk-bentuk konflik dan penyebab konflik akibat aktivitas pertambangan pada umumnya mencakup hal-hal sebagaimana diuraikan di atas. Contoh kasus konflik tersebut seperti yang terjadi di pesisir Teluk Banten. Aktivitas penambangan pasir laut di Teluk Banten diindikasikan merusak ekosistem Teluk Banten dan memberikan dampak terhadap penurunan pendapatan nelayan. Reaksi terhadap bentuk konflik ini berupa penolakan terhadap kegiatan penambangan pasir laut yang ditandai dengan maraknya demonstrasi penolakan terhadap kegiatan pertambangan (Juliannes Cadith : 2019, hal. 8). Begitu juga yang terjadi di Bangka Belitung, konflik yang muncul berupa penolakan masyarakat pesisir terhadap aktivitas tambang laut, bahkan sampai dengan berhentinya operasional perusahaan tambang di daerah tersebut. Disamping itu konflik yang terjadi dapat memecah belah masyarakat, sebagaimana dijelaskan oleh Sulista (Peneliti Provinsi Kepulauan Bangka Belitung), bahwa ada tiga model respon masyarakat pesisir terhadap penambangan laut. Pertama, sikap akomodatif dengan beberapa pertimbangan kompensasi, kedua, menolak dengan keras tanpa syarat, serta ketiga, sikap ganda masyarakat dengan implikasi pada keterbelahan masyarakat (www.babelprov.go.id)

\section{Program Keserasian Sosial sebagai kebijakan Dalam Penanganan Konflik.}

Kebijakan pemerintah dalam mengatasi konflik sosial salah satunya adalah Program Keserasian Sosial. Program Keserasian Sosial dapat dikatakan sebagai kebijakan publik, karena program ini dikeluarkan oleh Pemerintah melalui Kementerian Sosial RI sebagai entitas yang mempunyai tanggung jawab dan wewenang untuk mengatasi konflik sosial yang terjadi di masyarakat, sebagaimana disampaikan oleh Dian Fitriani Afifah dan Neneng 
Yani Yuningsih (2016 : hal. 335), bahwa Kebijakan merupakan suatu keputusan politis yang diambil oleh pemerintah sebagai bagian dari sikap pemerintah untuk mengatasi masalahmasalah yang berkaitan dengan persoalan publik. Sejalan dengan pendapat tersebut definisi kebijakan menurut Thomas R. Dye (2016) dalam Dian Fitriani Afifah dan Neneng Yani Yuningsih (2016 : hal. 336), merupakan pilihan-pilihan apapun untuk melakukan sesuatu maupun tidak melakukan sesuatu yang dapat diambil oleh pemerintah (whatever government choose to do or not to do). Program Keserasian Sosial yang merupakan pengembangan dari modal sosial untuk penanganan konflik, adalah berupa serangkaian sistem instrumen kebijakan yang dapat dipedomani dalam menangani suatu persoalan, dalam hal ini berkaitan dengan konflik yang terjadi antara masyarakat pesisir dengan pelaku pertambangan. Asumsinya keserasian sosial merupakan modal sosial masyarakat untuk melahirkan permufakatan bersama di dalam masyarakat untuk menjawab persoalan-persoalan yang mengarah pada terjadinya konflik sosial. Sementara itu menurut Rusydan Fathy (2019 : hal. 4), ketersediaan rasa saling percaya di dalam masyarakat (stocks of social trust), normanorma, dan jejaring yang dapat dimanfaatkan dalam rangka untuk menyelesaikan persoalanpersoalan bersama dapat dikatakan sebagai modal sosial (Lang \& Hornburg : 1998). Hal ini selaras dengan yang disampaikan oleh Nunung Hastika Ardiwijadja (2017: hal 17), bahwa Program keserasian sosial merupakan salah satu implementasi Kebijakan pemerintah dalam penanganan konflik, yang merupakan salah satu pengembangan dari unsur-unsur modal sosial untuk membangkitkan kepercayaan masyarakat dalam menangani masalah konflik yang terjadi di kehidupan masyarakat. Program keserasian sosial merupakan hubungan sosial antar warga secara harmonis dan penuh kedamaian serta upaya pencegahan terhadap potensi konflik yang ada di dalam masyarakat. Program keserasian sosial merupakan upaya pencegahan terhadap potensi konflik yang ada di masyarakat, melalui pendekatan manajemen risiko dalam menangani bencana sosial berbasis masyarakat. Keserasian sosial adalah suatu kondisi dalam kehidupan masyarakat yang dilandasi dengan semangat yang saling menghargai, saling menghormati antar warga dan antar komunitas masyarakat lokal. Keserasian sosial sebagai sebuah kebijakan diwujudkan dalam bentuk Peraturan Menteri Sosial RI Nomor 26 Tahun 2017 tentang Pelaksanaan Penanganan Konflik Sosial di Bidang Sosial. Dalam pedoman ini dijelaskan bahwa :

"Keserasian Sosial adalah kondisi sosial yang menjamin terciptanya relasi dan interaksi sosial antar warga masyarakat yang dinamis, selaras, dan seimbang untuk hidup berdampingan secara damai berdasarkan kesetaraan, kebersamaan, dan persaudaraan sejati" (pasal 1 : hal 3).

Berdasarkan Peraturan Menteri Sosial tersebut, Tujuan dari program keserasian sosial adalah untuk menciptakan suatu tatanan kehidupan sosial yang serasi dan harmonis yang dilandasi oleh nilai dasar kebersamaan, toleransi, saling menghargai dan menghormati, 
sehingga dapat membangun, memantapkan dan mengembangkan serta memelihara kembali kehidupan bersama di antara anggota masyarakat. Dalam kegiatan penerapannya program keserasian sosial dapat berbentuk kegiatan fisik maupun non fisik dengan melibatkan unsur masyarakat, khususnya masyarakat yang berkonflik.

\section{Implementasi Program Keserasian Sosial}

Untuk mengetahui sejauh mana Program Keserasian Sosial dapat menyelesaikan masalah konflik sosial yang terjadi dalam kehidupan masyarakat, dapat dilihat dari hasil kajian terhadap implementasi Program Keserasian Sosial yang telah diterapkan oleh pemerintah di beberapa daerah yang mengalami konflik sosial, seperti DKI Jakarta, Kota Makassar - Provinsi Sulawesi Selatan serta Kota Palu Provinsi Sulawesi Tengah. Karakteristik konflik yang terjadi berbeda-beda di setiap daerah. Begitu juga cara penanganannya pun berbeda-beda-beda. Pada kasus konflik sosial yang terjadi di DKI, konflik yang terjadi berupa bentrok fisik antar warga yang disebabkan oleh faktor kemiskinan. Sebagaimana dijelaskan oleh Nunung Hastika Ardiwijadja (2020 : hal 33), bahwa sumber permasalahan konflik di Jakarta Pusat adalah disebabkan karena banyaknya pengangguran, rumah dan lingkungan yang kumuh serta pendidikan yang rendah. Sedangkan Intervensi penanganannya lebih dititikberatkan pada kegiatan fisik. Hal ini dipertegaskan dengan pendapat Nunung Hastika Ardiwijadja (2020 : hal 32), yang menyatakan bahwa :

"Implementasi program keserasian sosial di DKI Jakarta sesuai dengan buku pedoman pelaksanaan keserasian sosial tahun 2010 dan 2011 meliputi: pembuatan taman masyarakat, taman bacaan, jalan setapak, perbaikan jalan warga perbaikan kakus atau WC umum, pemagaran taman, pembuatan pot bunga penghijauan, perbaikan sarana olah raga, alat musik dan pembuatan tugu. Lokasi pembuatan tugu perdamaian letaknya di antara kedua wilayah terjadinya bentrokan warga".

Dalam pelaksanaannya, Program Keserasian Sosial di DKI Jakarta belum dapat mengatasi konflik yang terjadi, karena secara nyata konflik dan bentrok masih tetap terjadi di daerah tersebut. Namun setidaknya daerah tersebut tidak lagi dikategorikan sebagai daerah yang rawan konflik, lebih lanjut dijelaskan oleh Nunung Hastika Ardiwijadja (2020 : hal 34), bahwa Implementasi Program Keserasian Sosial di DKI Jakarta secara fisik telah dilaksanakan sesuai dengan pedoman yang telah ditetapkan. Selanjutnya dijelaskan juga bahwa meskipun demikian, keberhasilan secara fungsional belum mencapai tujuan secara optimal, yaitu untuk mengembalikan dan mewujudkan kehidupan berdampingan secara damai, adil, selaras, harmonis dan seimbang di lokasi konflik. Hal ini disebabkan karena penerapan jenis Program Keserasian sosial di daerah rawan konflik masih fokus pada kegiatan fisik. Sedangkan kendala yang dihadapi untuk 
penanganan non fisik, yaitu mereka belum mampu memetakan sumber masalah konflik dan kebutuhan akan tokoh atau panutan yang mampu menghentikan konflik. (Nunung Hastika Ardiwijadja (2020 : hal 35).

Hampir sama dengan DKI Jakarta, di Makassar Provinsi Sulawesi Selatan, konflik yang terjadi berupa bentrok antar warga yang disebabkan karena faktor kemiskinan yang identik dengan pengangguran dan menempati tempat tinggal dan lingkungan yang kumuh. Sebagaimana dijelaskan oleh Setyo Sumarno dan Haryati Roebyantho (2013: hal 33), bahwa pemukiman padat penduduk, tidak ada ruangan untuk bergerak, tidak ada ruang untuk bermain anak-anak, pendidikan yang rendah serta mata pencaharian sebagai buruh, tukang becak, dll adalah sumber masalah antar warga di Kota Makassar. Sedangkan pemicunya adalah bersumber dari para wanita yang tidak memiliki mata pencaharian tetap. Program Keserasian Sosial di Makassar juga tidak berjalan sebagaimana mestinya dan belum memberikan manfaat sepenuhnya dalam mengatasi konflik yang terjadi. Pembangunan sarana prasarana untuk kepentingan umum seperti ruang pertemuan dan ruang bacaan dalam rangka menyatukan masyarakat yang berkonflik belum dapat memberikan pengaruh yang berarti, serta belum dapat mengurangi keikutsertaan warga ikut dalam terjadinya bentrok. Hal tersebut dijelaskan oleh Setyo Sumarno dan Haryati Roebiyantho (2013: hal 33) :

"Meskipun telah diadakan kesepakatan damai antara pelaku konflik dengan mendirikan tugu perdamaian, namun dalam kenyataan konflik dan bentrok masih tetap terjadi hingga hari ini. Artinya Forum Keserasian Sosial belum mampu menjangkau ke daerah konflik dan belum mampu menciptakan tatanan kehidupan sosial yang serasi dalam kehidupan bersama dalam masyarakat".

Berbeda dengan kedua daerah yang telah diuraikan tersebut di atas, penerapan Program Keserasian Sosial di Kota Palu - Sulawesi Tengah dilaksanakan di dua desa yang belum terjadinya konflik, tetapi merupakan daerah yang rawan dan berpotensi timbulnya konflik, yaitu dalam bentuk Program Keserasian Sosial Berbasis Masyarakat (KSBM). Gambaran tentang implementasi Program Keserasian Sosial Berbasis Masyarakat di Kota Palu dijelaskan oleh Azmi (2017 : hal. 195) diprioritaskan pada daerah-daerah rawan konflik sosial, diantaranya Kelurahan Pengawu dan Kelurahan Duyu. Program ini sudah terlaksana, namun pelaksanaan tersebut perlu didukung oleh semua masyarakat dan pihak-pihak yang terlibat dalam kegiatan tersebut. Disamping itu, lebih lanjut Azmi (2017 : 199-200) menjelaskan, bahwa berdasarkan penilaian terhadap 6 (enam) aspek model implementasi kebijakan Van Metter dan Van Horn, program keserasian sosial di Kota Palu belum terlaksana secara optimal, karena berdasarkan standar dan sasaran kebijakan kelompok sasaran, sebagian besar masyarakat belum memahami program KSBM. Dari aspek sumber daya, sebagian besar masyarakat mempunyai tingkat pendidikan dan ekonomi agak kurang, sehingga masyarakat kurang berpartisipasi dalam pelaksanaannya. Selain itu program ini 
belum didukung dengan dana yang memadai. Sedangkan untuk aspek karakteristik organisasi pelaksana, dan sikap para pelaksana kegiatan, sudah terjalin dengan baik, sehingga dapat mendukung pelaksanaan program tersebut. Sementara untuk aspek komunikasi antar organisasi pelaksana atau para implementor, meskipun sudah berjalan dengan baik tetapi komunikasi dengan masyarakat masih kurang, sehingga masyarakat kurang paham dan kurang berpartisipasi dalam pelaksanaan program. Faktor ekonomi masyarakat yang rendah juga mempengaruhi kurang optimalnya pelaksanaan program ini. Karena dalam pelaksanaannya tidak ada upah kerja, sehingga menyebabkan sebagian masyarakat kurang berpartisipasi untuk bergotong royong.

\section{PENUTUP}

Konflik sosial masih sering terjadi pada masyarakat pesisir, begitu juga yang terjadi di Provinsi Kepulauan Bangka Belitung. Persoalan pokok terjadinya konflik sosial disebabkan karena perbedaan kepentingan antara para nelayan dan pelaku tambang. Padahal pemerintah telah banyak mengeluarkan regulasi untuk mengatur pengelolaan sumber daya pesisir dan laut, khususnya masalah pertambangan. Pemerintah juga telah mengeluarkan kebijakan penanganan konflik sosial yang terjadi di beberapa daerah melalui pengembangan modal sosial yang ada di masyarakat. Namun dalam implementasinya kebijakan tersebut belum dapat memberikan hasil yang optimal.

Program Keserasian Sosial yang merupakan manifestasi dari pengembangan modal sosial dapat diterapkan untuk menangani masyarakat yang berkonflik, namun kebijakan tersebut perlu didukung oleh pihak-pihak yang berkonflik dengan menciptakan suatu sistem terpadu melalui konsep pemberdayaan (empowerment). Pendekatan penanganan melalui kegiatan pemberdayaan ekonomi masyarakat lebih diutamakan, karena sumber utama konflik yang terjadi pada masyarakat pesisir disebabkan oleh terganggunya sumber mata pencaharian masyarakat yang mengandalkan potensi sumber daya kelautan. Oleh sebab itu penulis merekomendasikan pengembangan program keserasian sosial sebagai berikut :

a. Program Keserasian Sosial perlu dikembangkan dengan cara mengintegrasikan dengan konsep pemberdayaan.

b. Pemberdayaan sosial dilaksanakan dengan meningkatkan nilai-nilai kesetiakawanan sosial berbasis kearifan lokal, yaitu dengan menumbuhkan budaya gotong royong dan saling tolong menolong yang sudah menjadi kebiasaan masyarakat. Menunjuk tokoh masyarakat yang menjadi panutan sebagai pelopor Program Keserasian Sosial.

c. Program Keserasian Sosial perlu didukung dengan pemberdayaan ekonomi, sehingga secara ekonomi masyarakat nelayan dapat terpenuhi disaat pekerjaan pokok sebagai nelayan terganggu secara alam.

d. Program Keserasian Sosial perlu didukung dengan kebijakan lain, khususnya kebijakan lingkungan hidup dan kebijakan pertambangan berkelanjutan. 


\section{DAFTAR PUSTAKA}

Ardiwijadja, N. (2017). Konflik Sosial dan Program Keserasian Sosial. SOSIOHUMANITAS, Vol 19 No. 2 Agustus 2017.

Azmi (2017). Implementasi Program Keserasian Sosial di Kota Palu Berbasis Masyarakat di Kota Palu. Katalogis. Vol 5 No 12 (2017). p-ISSN : 2302 - 2319.

Bidayani, Endang dan Kurniawan (2020). Resolusi Konflik Pemanfaatan Sumberdaya Pesisir antara Nelayan dengan Penambang Timah Inkonvensional. Society, 8 (1), 14-24, 2020 PISSN: 2338-6932 | E-ISSN: 2597-4874.

Cadith, Juliannes. (2019). Konflik dan Pemanfaatan Sumber Daya Pesisir. Jurnal Administrasi Publik. Vol 10 No 2 (2019). ISSN 2087-8923 eISSN 2549-9319

Darc Noviyanti Manik, Jeanne (2014). Kebijakan Pertambangan Laut Timah Yang Berdampak Pada Lingkungan. Journal article Promine Vol 2 No. 22014.

Dewi Sabda, Kartika (2018). Pelapisan Ssosial-Budaya Pesisir Kelurahan Mangkang Kulon Semarang. Sabda. Volume 13, Nomor 1, 28 Juni 2018, hal1. ISSN 1410-7910 E-ISSN 2549-16.

Fathy, Rusydan. (2019). Modal Sosial: Konsep, Inklusivitas dan Pemberdayaan Masyarakat. Jurnal Pemikiran Sosiologi Volume 6 No. 1, Januari 2019.

Fitri Afifah, Dian dan Yani Yuningsih, Neneng (2016). Analisis Kebijakan Pemerintah Tentang Pencegahan dan Penanganan Korban Perdagangan (Tarfficking) Perempuan dan Anak di Kabupaten CIanjur. CosmoGov, Vol.2 No.2, Oktober 2016. ISSN 2442-5958. E-ISSN $2540-8674$.

Mustamin, Drs, M.Si (2016). Studi Konflik Sosial di Desa Bugis dan Parangina Kecamatan Sape Kabupaten Bima Tahun 2014. Jurnal Ilmiah Mandala Education( JIME), Vol. 2. No. 2. Hal 186.

Sulista (2019). Tambang Inkonvesional : Peran Masyarakat dan Daya Tarik Ekonomi Bagi Penambang. Jurnal Teknologi Mineral dan Batubara Volume 15, Nomor 1, Januari 2019 : $63-75$.

Sumarno, Setyo dan Roebiyantho, Haryati. Evaluasi Program Keserasian Sosial Dalam Penanganan Konflik Sosial. Jakarta. 2013. P3KS Press

Wratsangka, Lantip \& Dhahiyat, Yayat, dan Sunardi (2014). Rencana Pengelolaan Konservasi Perairan Daerah Untuk Menjaga Kelestarian Ekosistem Terumbu Karang Dalam Upaya Meningkatkan Pendapatan Masyarakat (Studi Kasus Belitung Timur - Kepulauan Bangka Belitung ). IJAZ. Volume 4 No. 2 Edisi Agustus 2014 : Hal. 11.

http://jdih.babelprov.go.id/sites/default/files/produkhukum/PERGUB\%20NO.\%2024\%20TAHU N\%202017.pdf

https://mediaindonesia.com/read/detail/293475-walhi-babel-anggap-perdan-rzwp3k-bisa $\underline{\text { memiskinkan-nelayan }}$ 
ISSN 2088-7469 (Paper) ISSN 2407-6864 (Online)

Volume 10 Nomor 2 (2020)

https://finance.detik.com/energi/d-4391856/penerimaan-negara-dari-tambang-diklaim-tertinggiberapa-sih?

http://bappeda.babelprov.go.id/content/bappeda-babel-lakukan-penelitian-dampak-positifekonomi-dan-kerusakan-lingkungan-akibat

http://www.timah.com/v3/ina/keberlanjutan-statistik-bantuan-csr 